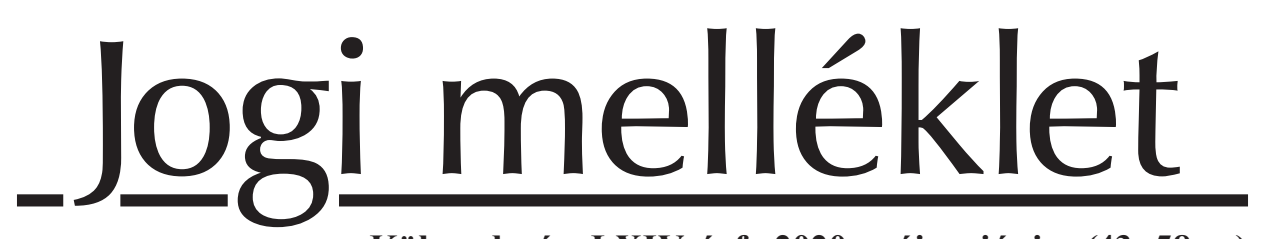

Külgazdaság, LXIV. évf., 2020. május-június (43-58. o.)

\title{
Brexit után: Az Európai Unió és az Egyesült Királyság együttmüködési lehetőségei a nemzetközi szankciók kivetésében
} SZÉP VIKTOR - PETER VAN ELSUWEGE

A brexit számos bizonytalanságot hozott felszínre a nemzetközi szankciók együttes alkalmazását illetően: miközben az Európai Unió és az Egyesült Királyság is elkötelezett az együttmüködés iránt, ma még nem világos, hogyan valósitható meg ez a kooperáció. Erre a kérdésre a tanulmány az uniós tagsággal nem rendelkezö európai államok tapasztalatával kíván válaszolni. A cikkáttekinti az érintett államokjogi környezetét, figyelembe veszi azonban a brit és uniós szakpolitikai dokumentumokat is, amelyek alapján különbözö forgatókönyveket állit fel. Az irás legföbb érve, hogy az Egyesült Királyság és az Európai Unió - szemben a szomszédos államok tapasztalataival - kölcsönös konzultációra épülö együttmüködést, és nem hierarchikus viszonyra épülö, egyirányú külpolitikai igazodást feltételezö formátumot hoznak létre.*

Journal of Economic Literature (JEL) kód: F15 Economic Integration, F10 General, F510 International Conflicts; Negotiations; Sanctions.

Kulcsszavak: Brexit; gazdasági szankciók; közös kereskedelempolitika; közös külés biztonságpolitika.

* A tanulmány a szerzők „EU Sanctions Policy and the Alignment of Third Countries: Relevant Experiences for the UK?” címmel megjelenő írásuk alapján, annak rövidített változataként készült. Lásd: Szép-Elsuwege [2020].

A kézirat első változata 2020. május 6-án érkezett szerkesztőségünkbe.

https://doi.org/10.47630/KULG.2020.64.5-6.43

Szép Viktor, tudományos segédmunkatárs. Társadalomtudományi Kutatóközpont, Jogtudományi Intézet - MTA Kiválósági Kutatóhely. E-mail: szep.viktor@tk.mta.hu

Peter Van Elsuwege, professor, Department of European, Public and International Law, Faculty of Law, University of Ghent. E-mail: peter.vanelsuwege@ugent.be 


\section{Bevezetés}

A kilépési megállapodás (Withdrawal Agreement) ${ }^{1}$ körüli heves brit belpolitikai viták után az Egyesült Királyság hivatalosan is elhagyta az Európai Uniót 2020. január 31-én. Jelen tanulmány írása pillanatában az Európai Unió (EU) és az Egyesült Királyság épp jövőbeli kapcsolataikat próbálják kialakítani. Ezen átmeneti időszak alatt - amely az eredeti tervek szerint 2020. december 31-ig tart - elsősorban a majdani kereskedelmi kapcsolatok részleteire összpontosítanak. Miközben a gazdasági viszonyrendszer kialakítása prioritást élvez, a jövőbeli kapcsolatokról szóló megállapodás része az átmeneti időszak utáni kül- és biztonságpolitikai együttmüködés is. Az erre szolgáló uniós keret (Közös Kül- és Biztonságpolitika - KKBP, a Közös Biztonság-és Védelempolitika - KBVP) nyilvánvalóan az Egyesült Királyság nélkül fog tovább müködni, amely kilépésével egyúttal elveszíti azt a lehetőségét, hogy belülről befolyásolja az uniós döntéshozatalt.

Mindezek nyomán felmerül a kérdés, hogy az EU és az Egyesült Királyság milyen keretek között tudja folytatni az együttműködést a kül- és biztonságpolitikai kérdésekben, s különösen a nemzetközi szankciók kivetésében. Teljesen nyilvánvaló, hogy mindkét fél érdekelt egy komoly együttmüködés létrehozásában, hiszen a brexit következtében nem szünnek meg a nemzetközi biztonságot fenyegető válságok (pl. ukrajnai válság vagy a közel-keleti kihívások). Az is egyértelmü, hogy az Egyesült Királyság tagja marad olyan nemzetközi szervezeteknek (pl. NATO vagy ENSZ BT), amelyek keretében együttmüködik az uniós tagállamokkal a nemzetközi biztonságot érintő kérdésekben. Ugyanakkor a két félnek eltérő elképzelései vannak az együttmüködésről: míg az Egyesült Királyság alapvetően abban érdekelt, hogy soha nem látott hozzáférést kapjon az uniós döntéshozatalhoz harmadik államként, addig az EU nem hajlandó ugyanolyan vagy hasonló jogokat biztosítani uniós tagsággal nem rendelkező államoknak, miközben nyilvánvalóan utóbbi is érdekelt egy komoly együttmúködés létrehozásában.

Ez a tanulmány a kül- és biztonságpolitikai együttmúködés egyetlen területén, a nemzetközi szankciók együttes alkalmazásában tekinti át a jövőbeli egységes fellépés lehetőségeit. A cikk először áttekinti a szankciók alkalmazására vonatkozó uniós jogi keretet, amely az Egyesült Királyságban egészen 2020. január 31-ig alkalmazandó volt. E rész egyik lényegi érve szerint a gazdasági és pénzügyi szankciók kivetése alapvetően uniós hatáskör, ezért alapvetően tiltott az egyoldalú tagállami fellépés.

${ }^{1}$ Lásd: Megállapodás a Nagy-Britannia és Észak-Írország Egyesült Királyságának az Európai Unióból és az Európai Atomenergia-közösségből történő kilépéséről. HL „C” 384 (2019.11.12.). 
Brexit után: Az Európai Unió és az Egyesült Királyság együttmüködési...

A második részben a tanulmány áttekinti, hogy az uniós tagsággal nem rendelkező európai államok hogyan kooperálnak az EU-val a szankciók kivetésében, ez egyúttal tanulság lehet az Egyesült Királyság számára is a jövőbeli együttmüködés tekintetében. Végül a cikk áttekinti a legújabb fejleményeket és a kormányzati, valamint uniós álláspontokat, és forgatókönyveket vázol fel az együttműködés lehetőségeire.

\section{A nemzetközi szankciók alkalmazására vonatkozó uniós jogi keret}

Az európai uniós tagság komoly következményekkel jár a tagállamok szankciós politikájára nézve. Ennek fényében kevésbé meglepő az a tény, hogy az Egyesült Királyság által végrehajtott korlátozó intézkedések túlnyomó többsége épp uniós tagságának következtében lépett hatályba. A szankciók alkalmazására vonatkozó alapszerződési rendelkezések jól tükrözik az EU és tagállamai közötti hatáskörmegosztást. A fegyverembargókat és utazási tilalmakat a Közös Kül- és Biztonságpolitika tanácsi határozat formájában fogadja el az EUSz 29. cikke alapján. E két típusú szankció alkalmazása alapvetően tagállami hatáskör maradt, de az alapszerződési rendelkezések lehetővé teszik, hogy a Tanács uniós szintủ szankciós rezsimeket fogadjon el. Ugyanakkor amennyiben az elöbb említett Közös Kül- és Biztonságpolitika határozata elöírja a gazdasági és/vagy pénzügyi szankciók alkalmazását is, akkor a Tanácsnak további jogi aktust kell elfogadnia. A Tanács a gazdasági és pénzügyi szankciókat az EUMSz 215. cikke alapján fogadja el rendeletek formájában. ${ }^{2} \mathrm{~A}$ brüsszeli mindennapokban eme két aktust (a tanácsi határozatot és a tanácsi rendeletet) egy napon fogadják el, hogy garantálják az azokban foglalt intézkedések azonnali hatálybalépését.

Amíg az Egyesült Királyság uniós tag volt, addig korlátozott hatáskörrel rendelkezett egyoldalú kereskedelmi szankciók kivetésére a közös kereskedelempolitika (KKP) széles körủ hatálya miatt. Mint az az Európai Unió Bírósága (EUB) ítéleteiből világossá válik, a közös kereskedelempolitika hatálya alá tartoznak azok a kereskedelempolitikai eszközök is, amelyeket kül- és biztonságpolitikai célok megvalósítása érdekében vetnek ki. Az a tény, hogy a gazdasági szankciók alkalmazása közvetlenül érinti az unió egyik kizárólagos hatáskör alá tartozó szakpolitikai területét, gátat szab az egyoldalú tagállami érdekérvényesítés lehetőségének és egyúttal kijelöli az uniós jogtól való eltérés határait. ${ }^{3}$

\footnotetext{
2 Lásd: Szép [2019].

3 Lásd: Szép [2019].
} 
Az EUB több alkalommal is felhívta a figyelmet arra, hogy a tagállamoknak tiszteletben kell tartaniuk uniós jogi kötelezettségeiket a tagállami szintủ kül- és biztonságpolitika kialakítása során is. Görögország 1990-es évekbeli egyoldalú kereskedelempolitikai fellépése is azt mutatja, hogy a Bizottság készen áll kötelezettségszegési eljárásokat indítani a tagállamok ellen, amennyiben úgy ítéli meg, hogy a kül- és biztonságpolitikai célok megvalósítása érdekében elfogadott (kereskedelempolitikai) eszközök megsértik az uniós jogot. Az említett esetben Görögország egyoldalú kereskedelmi szankciókat rendelt el Macedónia, volt Jugoszláv Köztársaság ellen, azon az alapon, hogy ez utóbbi megsértette területi egységét és nemzeti önazonosságát. Jacobs fötanácsnok indítványában hangsúlyozta, hogy a tagállamok átruházták hatáskörüket a kereskedelempolitika területén és ezzel egyúttal elfogadták, hogy egyoldalú intézkedések elfogadása alapvetően kizárt. Véleménye szerint még abban az esetben is elfogadhatatlan az egyoldalú kereskedelempolitikai eszközök alkalmazása, amennyiben azok tágabb kül- és biztonságpolitikai célokat szolgálnak. ${ }^{4} \mathrm{Az}$ ügyben nem született ítélet, mert Görögország végül visszavonta intézkedéseit. ${ }^{5}$ Ugyanakkor a Bíróságnak később alkalma nyílt a Centro-Com-ügyben, hogy megfogalmazzon egy általános elvet, amely szerint a tagállamoktól függ, hogy - saját hatáskörükön belül eljárva - milyen intézkedéseket fogadnak el a kül- és biztonságpolitika területén, de ezeknek az intézkedéseknek tiszteletben kell tartaniuk a Közösség által elfogadott kereskedelempolitikai rendelkezéseket a közös kereskedelempolitika területén. ${ }^{6}$

Bár az Egyesült Királyságot - mint bármelyik más uniós tagállamot - jelentős mértékben korlátozta az uniós jog abban, hogy egyoldalú kereskedelmi intézkedéseket fogadjon el, ez nem jelentette azt, hogy bizonyos feltételek teljesülése esetén ne alkalmazhatott volna nemzeti szinten elfogadott gazdasági szankciókat. Az EUMSz 347. cikke - amelyet elsősorban az 1960-as években alkalmaztak szankció kivetésére $^{7}$ - védi a tagállamok szuverenitását és előtérbe helyezi a partikuláris érdekek érvényesítését. ${ }^{8}$ Az EUMSz 347. cikke egyúttal elismerése annak, hogy a tagállamok megtartották hatáskörüket (vagy legalábbis annak nagy részét) a kül- és biztonság-

\footnotetext{
${ }^{4}$ Lásd: C-120/94 Bizottság kontra Görögország, Jacobs főtanácsnok 1995. április 6-i indítványa, ECLI:EU:C:1995:109.

5 Lásd: C-120/94 Bizottság kontra Görögország, a Bíróság elnökének 1996. március 19-i végzése, ECLI: EU:C:1996:116.

${ }^{6}$ Lásd: C-124/95 The Queen, ex parte Centro-Com kontra HM Treasury és Bank of England, ECLI: EU:C:1997:8. 23-30. bek.

${ }^{7}$ Lásd: Kuyper [1975].

${ }^{8}$ Lásd: Koutrakos [2000].
} 
politika végrehajtása során. ${ }^{9}$ A Bíróság azonban megerősítette az EUMSz 347. cikk „teljesen kivételes jellegét”, arra utalva, hogy a tagállamok csak rendkívüli körülmények fennállása esetén fogadhatnak el intézkedést az érintett rendelkezésre alapozva. ${ }^{10}$ Ráadásul az EUMSz 347. cikkre való hivatkozás egyúttal felveti azt a kérdést is, hogy a tagállamok nem élnek-e vissza az unió hatásköreivel, ugyanis a gazdasági és pénzügyi szankciókat jelenleg alapvetően az EUMSz 215. cikke alapján kell elfogadni. Azt is megállapították, hogy az ENSZ-szankciók végrehajtását szintén nem lehet az EUMSz 347. cikkére alapozni, hiszen a nemzetközi jogi kötelezettségeknek való megfelelést szintén garantálják az alapszerződési rendelkezések. ${ }^{11}$ Mindezek eredményeképpen a gazdasági és pénzügyi szankciókat alapvetően a Tanács fogadja el, amelyek később a European Communities Act 1972 második szakasza alapján léptek hatályba a brit jogban. ${ }^{12}$

Az Egyesült Királyságot komolyan korlátozta az uniós jog a kettős felhasználású termékek területén is. Míg egy kisszámú kettős felhasználású termékről a brit jog önállóan rendelkezhet, ${ }^{13}$ a kettős felhasználású termékek forgalmára vonatkozó uniós szabályokat a Tanács 428/2009/EK rendelete határozza meg, ${ }^{14}$ ennek alkalmazását a brit jog is szavatolja. A kettős felhasználású termékek exportja szintén felvetette azt a kérdést, hogy a közös kereskedelempolitika hatálya lefedi-e a kül- és biztonságpolitikai célokkal rendelkező kereskedelempolitikai eszközöket. A Werner-ügyben a német hatóságok visszautasítottak vákuum indukciós olvasztókra és öntöttvas sütőkre vonatkozó exportkérelmet azon az alapon, hogy azok kivitele veszélyezteti az ország kül- és biztonságpolitikai érdekeit. ${ }^{15} \mathrm{~A}$ Leifer-ügyben pedig büntetőeljárást indítottak három személy ellen, mert olyan termékeket szállítottak Irakba 1984 és 1988 között, amelyek megsértették a német külkereskedelmi törvényt. ${ }^{16}$ Az EUB mindkét esetben kimondta, hogy azok az intézkedések, amelyek megakadályozzák

${ }^{9}$ Lásd: C-120/94 Bizottság kontra Görögország, Jacobs fötanácsnok 1995. április 6-i indítványa, ECLI:EU:C:1995:109.

${ }^{10}$ Lásd: C-222/84 Johnston kontra Chief Constable of the Royal Ulster Constabulary, ECLI: EU:C:1986:206, 27. bek.

${ }^{11}$ Lásd: Koutrakos [2000].

12 Lásd: European Communities Act 1972.

13 Lásd különös tekintettel: The Export Control Order 2008.

${ }^{14}$ Lásd: A Tanács 428/2009/EK rendelete (2009. május 5.) a kettős felhasználású termékek kivitelére, transzferjére, brókertevékenységére és tranzitjára vonatkozó közösségi ellenőrzési rendszer kialakításáról.

${ }^{15}$ Lásd: C-70/94 Fritz Werner Industrie-Ausrüstungen GmbH kontra Federal Republic of Germany, ECLI: EU:C:1995:328.

${ }^{16}$ Lásd: C-83/94 Leifer és társai. Peter Leifer, Reinhold Otto Krauskopf és Otto Holzer elleni büntetőeljárás. ECLI: EU:C:1995:329. 
vagy korlátozzák bizonyos termékek exportját, nem kezelhetők úgy, mint amelyek a közös kereskedelempolitika hatályán kívül esnek azon az alapon, hogy azok kül- és biztonságpolitikai célokat szolgálnak. ${ }^{17}$

A fegyverexport alapvetően viszont tagállami hatáskör maradt - amely ről az EUMSz 346. cikk (1) bekezdés (b) pontja is tanúskodik -, még annak ellenére is, hogy ennek komoly kereskedelempolitikai vonzatai vannak. Azonban eme cikkre nem lehet korlátlanul hivatkozni. Elegendő csupán utalni a Tanács 2008/944/KKBP közös álláspontjára, amely meghatározta a katonai technológia és felszerelések kivitelének ellenőrzésére vonatkozó közös szabályokat. ${ }^{18}$ Ez a közös álláspont nyolc olyan kritériumot határoz meg, amely alapján az exportengedélyeket kiadják. A Consolidated EU and National Arms Export Licensing Criteria szó szerint átemelte ezt a közös álláspontot a brit jogba, ez lehetővé teszi a brit hatóságok számára, hogy értékeljék az exportengedélyeket. Az uniós szintủ fegyverembargókat pedig az Export Control Order 2008 tette lehetővé és egyúttal emelte be a brit jogba.

Az Egyesült Királyság nemzeti jogába átültette az Európai Unió Tanácsa által elrendelt utazási korlátozásokat. ${ }^{19}$ Ezzel egy időben az Egyesült Királyságnak hatásköre volt egyoldalú utazási korlátozások elrendelésére, ezek alapján elrendelhette a nem EGT-állampolgárok belépési tilalmát. A bevándorlási szabályok lehetővé tették a kormánynak, hogy megtagadja a belépést azon az alapon, hogy képes legyen fenntartani a nemzetbiztonságot és a terrorizmus elleni fellépést. A belépés az Egyesült Királyság területére megtiltható, amennyiben úgy ítélik meg, hogy az érintett személy veszélyezteti a közbiztonságot. ${ }^{20}$

\section{Uniós tagsággal nem rendelkező európai államok gyakorlata az uniós szankciók végrehajtására}

Az előző részben áttekintettük a szankciók alkalmazására vonatkozó uniós jogi kötelezettségeket, ezek alapján kijelenthető: az uniós tagállamokat - köztük korábban az Egyesült Királyságot - komoly jogi kötelezettségek terhelték, amikor

${ }^{17}$ Lásd: C-70/94 Fritz Werner Industrie-Ausrüstungen GmbH kontra Federal Republic of Germany, ECLI: EU:C:1995:328. 9-30. bek.

${ }^{18}$ Lásd: A Tanács 2008/944/KKBP Közös Álláspontja (2008. december 8.) a katonai technológia és felszerelések kivitelének ellenőrzésére vonatkozó közös szabályok meghatározásáról.

${ }^{19}$ Lásd: Immigration Act 1971, Section 8B.

${ }^{20}$ Lásd: Immigration Rules part 9: General grounds for the refusal of entry clearance, leave to enter or variation of leave to enter or remain in the United Kingdom, paragraph 320 (6). 
Brexit után: Az Európai Unió és az Egyesült Királyság együttmüködési...

mérlegelték az egyoldalú kereskedelmi intézkedések bevezetését. Ez a jogi kötöttség nyilván megszünik abban a pillanatban, amikor egy tagállam elhagyja az uniót (pl. egy megegyezés nélküli kilépés esetén), de legkésőbb a kilépési megállapodás (Withdrawal Agreement) által meghatározott átmeneti időszak végén. Az Egyesült Királyságnak természetesen továbbra is meg kell felelnie nemzetközi jogi kötelezettségeinek, ám arra nem kényszeríthető, hogy átvegye az uniós szankciókat saját nemzeti jogrendszerébe.

Bár a jogi helyzet jelenleg viszonylag egyértelmủ, politikailag korántsem világos, hogy az átmeneti időszakot követően hogyan fog az EU és az Egyesült Királyság együttmüködni a szankciók kivetésében (illetve tágabban: a kül-, biztonság- és védelempolitika területén). Teljesen nyilvánvaló, hogy a két fél továbbra is érdekelt a kül- és biztonságpolitikai együttműködésben, hiszen a közös fenyegetettségek és kihívások, valamint a két fél értékei nem változnak a britek távozásával. Ráadásul - ahogyan erre a korábbiakban már utaltunk - az Egyesült Királyság tagja marad a nemzetközi kapcsolatokat és biztonságot meghatározó nemzetközi szervezeteknek, így elsősorban a NATO- és az ENSZ BT-tagságát senki nem kérdőjelezi meg. A két felet arra kényszerítik a közös kihívások és fenyegetettségek, hogy együttmüködjenek a kül-, biztonság- és védelempolitika területén. Ráadásul a szankciók hatékonysága abban az esetben garantálható, ha minél több szereplő hasonló intézkedéseket fogad el. ${ }^{21}$

Ugyanakkor jelenleg nem világos, hogy az átmeneti időszak után hogyan tud együttmúködni az EU és az Egyesült Királyság a szankciós politika területén. A jövőbeni együttműködés alapjait meghatározó politikai nyilatkozat (Political Declaration ${ }^{22}$ csupán homályos utalást tesz a konzultáció és az együttmüködés szükségességéröl. Tovább bonyolítja a helyzetet, hogy az Egyesült Királyság dönthet úgy, hogy a szankció kivetésében más szereplőkkel, így elsősorban például az Egyesült Államokkal kíván komolyabb együttműködést létrehozni. Az ENSZ BT állandó tagsága és a nemzetközi kapcsolatokban meghatározó szerepe következtében elképzelhető egy olyan forgatókönyv is, amely alapján a britek önálló szereplővé akarnak válni a brexit-kampány fö üzenetének fényében (,Taking back control”).

${ }^{21}$ Lásd: De Vrie-Portela-Guijarro-Usobiaga [2014].

${ }^{22}$ Lásd: Politikai nyilatkozat az Európai Unió és az Egyesült Királyság közötti jövőbeli kapcsolatok keretének meghatározásáról, HL „C” 66 (2019.2.19.). A 2019 októberében módosított szöveg magyarul nem elérhetó, lásd: Revised political declaration setting out the framework for the future relationship between the European Union and the United Kingdom.

Letölthetö: https://ec.europa.eu/commission/publications/revised-political-declaration_en. 
Ebben az olvasatban a britek befolyásolják (rule-maker) a nemzetközi kapcsolatokat, nem átveszik (rule-taker) más szereplők hasonló intézkedéseit.

Eközben nem lehet kizárni, hogy az Egyesült Királyság alkalmazkodni kényszerül (rule-taker) más globális szereplők által diktált külpolitikai álláspontokhoz. Az unió külügyi és biztonságpolitikai főképviselöje (továbbiakban: Főképviselö) minden alkalommal, amikor az unió szankciókat alkalmaz, meghívja az uniós tagsággal nem rendelkező európai államokat, hogy igazítsák saját külpolitikájukat az unióhoz. ${ }^{23}$ Az EU alapvetően négy országcsoportot hív meg: az EFTA-államok közül Izlandot, Liechtensteint és Norvégiát (Svájcot tehát nem, a magyarázatot lásd később), a tagjelölt és potenciális tagjelölt államokat, valamint a Keleti Partnerség valamennyi partnerállamát. A meghívás elfogadása - mint azt az egyes esetek mutatják - az eltérő politikai és jogi környezet miatt nagyon változó képet mutat. Általában igaz, hogy a tagjelölt országok az összes uniós szankciós rezsimet átültetik saját nemzeti jogrendszereikbe. Ennek egyszerủ oka van: a Közös Kül- és Biztonságpolitika határozatai az acquis részét képezik, amelyet a tagjelölteknek át kell ültetniük, amennyiben az unió tagjává kívánnak válni. Természetesen van kivétel: Törökország régóta részt vesz a csatlakozási folyamatban, de a tagjelöltekhez képest viszonylag alacsony számú közös kül- és biztonságpolitikai nyilatkozatot és határozatot hajlandó átültetni. Izland, Liechtenstein és Norvégia hasonlóan aktív partnernek bizonyulnak, ám utóbbiakat jogilag nem kötelezi semmi arra, hogy átvegyék az uniós szankciókat. Mégis megbízható partnerek, hiszen azonosulnak az EU értékeivel, illetve a közös fenyegetettségek együttműködésre kényszerítik a feleket.

Mindezek fényében érdemes megnézni, hogy szolgálhat-e az Egyesült Királyság számára tanulságként az uniós tagsággal nem rendelkező európai államok példája. A következőkben áttekintjük néhány európai állam példáján keresztül, hogy milyen jogi környezetet alakítottak ki annak érdekében, hogy képesek legyenek együttmüködni az EU-val a szankciók kivetésében.

A tagjelölt országok - ahogy arra már utaltunk - általában végrehajtanak minden uniós szankciós rezsimet. Némi bizonytalanságot jelent az a tény, hogy az uniós szankciókat a közös kül- és biztonságpolitikai határozatok és tanácsi rendeletek formájában is elfogadják, így felmerül a kérdés, hogy előbbiek is részei-e az acquis-nak? Mint arra azonban többen is felhívják a figyelmet, a közös kül- és biztonságpolitikai hatá-

${ }^{23}$ Lásd például: A főképviselőnek az EU nevében tett nyilatkozata egyes országoknak a Mianmarral/Burmával szembeni korlátozó intézkedésekhez történő csatlakozásáról. Council of the European Union. Letölthető: https:/www.consilium.europa.eu/hu/press/press-releases/2020/05/18/declarationby-the-high-representative-on-behalf-of-the-eu-on-the-alignment-of-certain-countries-concerningrestrictive-measures-against-myanmar-burma/. 
Brexit után: Az Európai Unió és az Egyesült Királyság együttmüködési...

rozatok az acquis részei, azokat a tagjelölt államoknak végre kell hajtaniuk, amenynyiben csatlakozni kívánnak az unióhoz. ${ }^{24}$ Horvátország például az uniós szankciós rezsimek 98 százalékát végrehajtotta a 2013-as csatlakozás előtt. ${ }^{25}$

Meg kell jegyezni ugyanakkor, hogy nem minden tagjelölt hajlandó hozzáigazítani saját külpolitikáját az unióhoz. Különösen Törökország bizonyult vonakodó partnernek a közös szankciós rezsimek kialakítása során, amit nyilván megmagyaráz az ország elhúzódó csatlakozási folyamata, valamint jelentősen eltérő kül- és biztonságpolitikai érdekei. Az Európai Bizottság évente közzétett országjelentései is megerősítik, hogy Törökország más tagjelölt országokhoz képest számottevően kevesebb közös kül- és biztonságpolitikai nyilatkozathoz csatlakozott. ${ }^{26}$ Bár a 2000 -es évek közepén üdvözölték Törökország fokozódó együttmüködési kedvét a külpolitikai kérdésekben, a Bizottság 2014-es jelentése szerint Ankara „közepesen felkészült a kül-, a biztonság- és a védelempolitika területén". ${ }^{27}$ Egy későbbi jelentés azt is hangsúlyozza, hogy Törökország 2018 és 2019 között a 87-ből mindösszesen 16 közös kül- és biztonságpolitikai nyilatkozathoz csatlakozott. ${ }^{28}$ Törökország és Szerbia azon kevés európai ország közé tartozik, amelyek nem csatlakoztak az Oroszországgal szemben bevezetett uniós szankciókhoz. Szerbia esete ugyanakkor - tekintve az ország csatlakozási ambícióját - mégis más. Amellett, hogy az előcsatlakozás során külön figyelmet szentelnek a kül- és biztonságpolitikai kérdésekre, a Stabilizációs és Társulási Megállapodás kiemeli a külpolitikai álláspontok konvergenciájának fontosságát. ${ }^{29}$ Ugyanakkor a Főképviselő felhívta Szerbia figyelmét, hogy végre kell hajtania az uniós korlátozó intézkedéseket, beleértve az Oroszországgal szemben bevezetett szankciókat is, máskülönben kérdéses lehet az ország uniós csatlakozá$\mathrm{sa}^{30}$

${ }^{24}$ Lásd: Cardwell [2016].

${ }^{25}$ Lásd: Szép-Van Elsuwege [2020].

${ }^{26}$ Lásd: Regular Report on Turkey's progress towards accession. European Commission. Letölthető: https://ec.europa.eu/neighbourhood-enlargement/sites/near/files/archives/pdf/key_documents/2004/rr_tr_2004_en.pdf.

${ }^{27}$ Lásd: Turkey Progress Report 2014. European Commission. Letölthető: https://ec.europa.eu/ neighbourhood-enlargement/sites/near/files/pdf/key_documents/2014/20141008-turkey-progress-report_en.pdf

${ }^{28}$ Lásd: Commission Staff Working Document: Turkey 2019 Report. Accompanying the document Communication from the Commission to the European Parliament, the Council, the European Economic and Social Committee and the Committee of the Regions. European Commission. Letölthető: https://ec.europa.eu/neighbourhood-enlargement/sites/near/files/20190529-turkey-report.pdf.

${ }^{29}$ Lásd: Stabilizációs és Társulási Megállapodás 10. cikk (2) bekezdése.

${ }^{30}$ Lásd: Answer given by High Representative/Vice-President of the Commission Ashton on behalf of the Commission. European Parliament. Letölthetö: https://www.europarl.europa.eu/sides/getAllAnswers.do? reference $=E-2014-004106 \&$ language $=E N$. 
Bizonyos szempontból hasonló képet mutat az említett három EFTA-állam: Norvégia, Liechtenstein és Izland végrehajtja az uniós szankciók 80-90 százalékát. ${ }^{31}$ Ennek egyik oka, hogy ezek az országok egyetértenek az unió alapvető értékeivel és - ami talán fontosabb - érdekeik is azt diktálják, hogy együttmüködjenek az unióval. A közös fenyegetettségek és kihívások, valamint a hatékony külpolitikai fellépés iránti elkötelezettség nyilvánvalóan kollektív cselekvésre készteti a feleket. Ugyanakkor bizonyos szempontból teljesen más a jogi helyzetük, mint a tagjelölt országoké: alapvetően nincs jogi kötelezettségük arra nézve, hogy külpolitikai kérdésekben együttmüködjenek az unióval. Ezek az országok jelenleg nem kívánnak az unió tagjává válni, így nem kell végrehajtaniuk a teljes acquis-t. Az Európai Gazdasági Térségről szóló Megállapodás nem terjed ki a kül- és biztonságpolitikai együttműködésre. Meg kell jegyezni ugyanakkor, hogy a Megállapodáshoz csatolt, jogilag nem kötelező erejü nyilatkozatok előirányozzák a politikai párbeszédet és megerősítik a külpolitikai együttműködés fontosságát. ${ }^{32}$ A Föképviselő ezeket az országokat is meghívja, hogy csatlakozzanak az unió szankciós rezsimjeihez.

Norvégia az 1980-as évek közepéig elsősorban az ENSZ BT határozatait hajtotta végre. Ugyanakkor 1985-ben megállapodást kötött az Európai Közösség tagjaival, hogy informális csatornákon együttműködést hoznak létre az Európai Politikai Együttmüködés keretén belül, amelynek eredményeképp napjainkra Norvégia végrehajtja az uniós szankciós rezsimek többségét. ${ }^{33}$ A Sanctions Act 2001 lehetővé teszi az ország számára, hogy csatlakozzon az EU és más nemzetközi szervezetek nem katonai intézkedéseihez, amelyeket kormányrendeletek formájában hajtanak végre. ${ }^{34} \mathrm{~A}$ statisztikák azt mutatják, hogy Norvégia az EU szankciós rezsimjeinek 90 százalékát végrehajtja, ez azt bizonyítja, hogy szinte automatikusan átveszi az uniós korlátozó intézkedéseket. ${ }^{35}$ A nagyfokú együttmüködésnek részben az az oka, hogy Norvégia számos olyan szankciós rezsimet vesz át, amely nem sérti alapvetően nemzeti érdekeit, ugyanakkor teljesíti azon várakozásokat, amelyek alapján bizonyos alapvető értékek fenntartásához szükséges a szankciók kivetése. Egyúttal megtartotta azon jogát, hogy visszautasítsa olyan szankciós rezsimek végrehajtását, amelyek alapvetően sértik kereskedelmi érdekeit.

Svájc esete a norvég példával összehasonlítva jelentős eltéréseket mutat, tekintve hogy történelmileg meghatározott semlegessége máig meghatározza az ország

${ }^{31}$ Lásd: Szép-Elsuwege [2020].

32 Lásd: Megállapodás az Európai Gazdasági Térségröl, OJ L 1, 3.1.1994, 3-522. o.

${ }^{33}$ Lásd: Szép-Van Elsuwege [2020].

${ }^{34}$ Lásd: Act of 27 April 2001. Letölthető: https://lovdata.no/dokument/NL/lov/2001-04-27-14.

${ }^{35}$ Lásd: Szép-Elsuwege [2020]. 
Brexit után: Az Európai Unió és az Egyesült Királyság együttmüködési...

viszonylagosan alacsony intenzitású együttműködési hajlandóságát a szankciós politika területén. A semlegességet előtérbe helyező ország álláspontját az is jól tükrözi, hogy csupán az 1990-es években bírálta felül korábbi álláspontját, miszerint az ENSZ BT szankciói összeférhetetlenek saját alkotmányos identitásával ${ }^{36}$ és csupán 2002-ben döntött az ENSZ-hez való csatlakozás mellett. A kezdeti időszakban már meglévő jogszabályokat (pl. Loi sur le materiel de guerre ${ }^{37}$ vagy Loi sur le contrôle des biens à des fins civiles et militaires ${ }^{38}$ ) használt a fegyverembargók eseti elbírálására és végrehajtására. Amennyiben más típusú szankciók végrehajtását helyezték kilátásba, akkor a Szövetségi Tanács egy végrehajtási rendeletet fogadott el az Alkotmány 102. cikk (8) és (9) bekezdése alapján, majd később, az új alkotmány hatálybalépését követően (2000. január 1.) ugyanezeket a végrehajtási rendeleteket a 184. cikk alapján fogadták el. Jelentős változás 2003-ban következett be, amikor hatályba lépett egy önálló jogszabály, amelyet kifejezetten azért hoztak létre, hogy Svájc képes legyen átvenni eseti alapon a nemzetközi szankciókat (Loi fédérale sur l'application de sanctions internationales). ${ }^{39}$ Ez utóbbit azzal az explicit céllal fogadták el, hogy Svájc képes legyen átvenni az EU, az EBESZ és más nemzetközi szervezetek által kivetett szankciókat. Ezzel együtt a svájci kormány továbbra is hangsúlyozza, hogy az új keretjogszabály nem jelenti azt, hogy automatikusan átemelne szankciós rezsimeket saját jogrendszerébe; azokat továbbra is eseti jelleggel megvizsgálja, és eldönti, hogy végrehajtja-e szankciókat, vagy sem. ${ }^{40}$

A Keleti Partnerség országai között jelentős eltéréseket lehet tapasztalni abban a kérdésben, hogy mennyire hajlandók végrehajtani az uniós szintű korlátozó intézkedéseket. Az EU-val kötött eltérő bilaterális egyezmények nagyrészt megmagyarázzák eme nagyfokú eltérést. Az Ukrajnával vagy Moldovával kötött Társulási Megállapodások (Association Agreements) már nem csupán együttműködést irányoznak elö, hanem egyenesen külpolitikai konvergenciáról beszélnek, ami rendszerszintü igazodást feltételez a gyakorlatban. ${ }^{41}$ Ezzel szemben az Örményországgal kötött

${ }^{36}$ Lásd: Rapport sur la politique extérieure de la Suisse dans les années 90 (1993), 169. Letölthető: https://www.amtsdruckschriften.bar.admin.ch/viewOrigDoc.do?id=10107650.

37 Lásd: Loi fédérale sur le matériel de guerre 1996. Letölthető: https:/www.admin.ch/opc/fr/ classifiedcompilation/19960753/index.html.

38 Loi fédérale sur le contrôle des biens utilisables à des fins civiles et militaires, des biens militaires spécifiques et des biens stratégiques 1996. Letölthető: https:/www.admin.ch/opc/fr/classifiedcompilation/19960740/index.html.

39 Lásd: Loi fédérale sur l'application de sanctions internationales 2003. Letölthetö: https://www. admin.ch/opc/fr/classifiedcompilation/20000358/index.html.

40 Lásd: Szép-Van Elsuwege [2020].

${ }^{41}$ Lásd: Van der Loo [2016]. 
Átfogó és Megerősített Partnerségi Megállapodás (Comprehensive and Enhanced Partnership Agreement) csupán általánosabb jellegủ utalást tesz a politikai párbeszédre anélkül, hogy említené a külpolitikai álláspontok konvergenciáját. ${ }^{42}$

\section{A jövőbeli együttmúködésre tett erőfeszítések}

Az Egyesült Királyság 2017-től új törvényt készített elő a nemzetközi szankciók kivetésére. A European Union (Withdrawal) Act 2018 lehetővé teszi, hogy az összes uniós szankciós rezsimet átültessék a brit jogrendszerbe. Ugyanakkor a Withdrawal Act nem alkalmas arra, hogy az Egyesült Királyság módosítsa ezeket a szankciós rezsimeket a kilépés után. Mindez azzal a következménnyel jár, hogy új nemzeti jogszabályt kellett elfogadni, amely lehetővé teszi a nemzetközi jogi kötelezettségeknek való megfelelést és egy autonóm szankciós politika kialakítását is. ${ }^{43}$ Mindezeknek a fényében a brit kormány kiadott egy fehér könyvet 2017 áprilisában és kezdeményezte a nemzeti szankciós politika jogi keretéről szóló nyilvános konzultáció megindítását. ${ }^{44}$ A folyamatot 2017 augusztusában zárták le, ennek eredményeképp elfogadták a Sanctions and Anti-Money Laundering Act 2018-at. ${ }^{45}$ Az új törvény felhatalmazza az érintett minisztert, hogy rendeleteket fogadjon el nemzetközi szankciók kivetésekor.

Figyelemre méltó ugyanakkor az a tény, hogy az Egyesült Királyságban az átmeneti időszak végéig (előreláthatóan 2020. december 31-ig) továbbra is alkalmazni kell az uniós jogot a kilépési megállapodás (Withdrawal Agreement) értelmében. ${ }^{46}$ Mindez komoly következményekkel jár a brit szankciós politikára ebben az időszakban, hiszen várhatóan az összes uniós szankciót átültetik nemzeti jogrendszerükbe 2020 végéig. Ugyanakkor az Egyezmény 129. cikk (6) bekezdése lehetőséget biztosít az Egyesült Királyság számára, hogy létfontosságú nemzeti érdekeire hivatkozva

${ }^{42}$ Lásd: Szép-Van Elsuwege [2020].

${ }^{43}$ Lásd: Exploratory notes to the Sanctions and Anti-Money Laundering Act 2018. Letölthetö: http://www.legislation.gov.uk/ukpga/2018/13/resources, para 12-13.

${ }^{44}$ Lásd: Public consultation on the United Kingdom's future legal framework for imposing and implementing sanctions. Foreign and Commonwealth Office, HM Treasury, Department for International Trade. Letölthető: https://www.gov.uk/government/consultations/public-consultation-on-the-united-kingdomsfuture-legal-framework-for-imposing-and-implementing-sanctions.

${ }^{45}$ Lásd: Sanctions and Anti-Money Laundering Act 2018. Letölthető: https://services.parliament. uk/bills/2017-19/sanctionsandantimoneylaundering.html.

${ }^{46}$ Lásd: European Union (Withdrawal Agreement) Bill: Explanatory Notes. Letölthető: https:// publications.parliament.uk/pa/bills/cbill/2019-2019/0007/en3/20007en.pdf, para 19. 
figyelmen kívül hagyja a közös kül- és biztonságpolitikai határozatok végrehajtását, amennyiben ezt formálisan jelzi a Főképviselönek. Miközben az Egyezmény lehetőséget kínál az Egyesült Királyság számára, hogy bizonyos szankciók átültetését figyelmen kívül hagyja, az Egyezmény felhívja a figyelmet arra, hogy ebben az esetben az Egyesült Királyságnak - a kölcsönös szolidaritás szellemében - tartózkodnia kell minden olyan fellépésétől, amely összeegyeztethetetlen lenne vagy egyenesen megakadályozná az EU külkapcsolati fellépéseit. Másképp szólva, a briteknek lojálisan kell eljárniuk az EU-val szemben az átmeneti időszak alatt, és nem áshatják alá az EU szankciós politikáját azzal, hogy kivételes körülményekre való hivatkozással nem ültetnek át bizonyos közös kül- és biztonságpolitikai határozatokat.

Mindezekkel együtt teljesen világos, hogy az Egyesült Királyság önálló szankciós politikát alakíthat ki, kiváltképp az átmeneti időszakot követően, és már nem fogja kötni az uniós jog eme eszközök kivetésekor. Ugyanakkor mind a brit kormány, mind pedig az EU kifejezte azon várakozásait, miszerint a kül- és biztonságpolitika területén is komoly kapcsolatot kívánnak létrehozni. A korábbi miniszterelnök, Theresa May többször is javasolta, hogy erös és szoros partnerséget építsenek ki. ${ }^{47}$ A brexit fötárgyaló, Michel Barnier és a korábbi Főképviselő, Federica Mogherini hasonlóan fontosnak tartják a külpolitikai együttmüködést a brexit után. ${ }^{48}$ Elméletileg három forgatókönyv valószínűsíthető. ${ }^{49} \mathrm{Az}$ Egyesült Királyság érdekeit leginkább egy olyan együttműködési forma elégítené ki, amely egyfajta integráció nélküli tagságot biztosítana számára az uniós intézményekben, különösen pedig a Külügyek Tanácsában és a Politikai és Biztonsági Bizottságban. E modell legföbb akadálya, hogy nehéz - hacsak nem lehetetlen - összeegyeztetni az EU saját magáról alkotott képével, különösképp a stratégiai autonómiával. Nem mellékes az a tényező sem, hogy az unió nem kíván harmadik államoknak az uniós tagállamokéval megegyező mértékű jogokat biztosítani. ${ }^{50}$ Alternatív megoldás lehetne egy intézményi-

${ }^{47}$ Lásd: House of Lords, European Union Committee, 'Brexit: Sanctions Policy', 8th Report of Session 2017-19. Letölthetö: https://publications.parliament.uk/pa/ld201719/ldselect/ldeucom/50/50. pdf.

${ }^{48}$ Lásd: Speeches by Michel Barnier and Federica Mogherini at the EU Institute for Security Studies Conference. Letölthető: https://eeas.europa.eu/headquarters/headquartershomepage/44486/ brexit-mogherini-and-barnier-discuss-eu-foreign-and-security-policy-post-brexit-live1700_id.

${ }^{49}$ Whitman [2016] szerint az Egyesült Királyság integrált, társult és különálló partner is lehet.

${ }^{50}$ Lásd: Federica Mogherini a következöket mondta ezzel kapcsolatban: "Britain will not be a 'half-member' or a member 'ad honorem' ... either you are a member or you are not". Remarks by HR/ VP Mogherini at the EU Institute for Security Studies event on „The future of EU foreign, security, and defence policy post Brexit". Letölthetö: https://eeas.europa.eu/headquarters/headQuarters-homepage/44528/remarks-hrvp-mogherini-eu-institute-security-studies-event-future-eu-foreign-securityand_en. 
leg jobban megalapozott, norvég mintára létrehozandó strukturális konzultáció. Végül pedig az Egyesült Királyság követhetné az Egyesült Államok példáját, ez alapján a tagállamokkal és az Európai Külügyi Szolgálattal fenntartott informális kapcsolati hálókon keresztül próbálnák harmonizálni a korlátozó intézkedéseket.

Miközben minden szereplő számára világos, hogy a szankciók akkor a leghatékonyabbak, amennyiben azokat összehangolják, az Egyesült Királyság inkább saját vezető szerepét hangsúlyozza a szankciós politika területén, és kiemeli, hogy az ENSZ BT állandó tagságát e folyamatok befolyásolására kívánja felhasználni. A vezető szerepét nem látja ugyanakkor veszélyeztetve, ha bizonyos esetekben együttműködik más szereplőkkel, de hangsúlyozza az ország saját hatáskörét eme területen. ${ }^{51}$

A gyakorlatban ez azt jelentheti - az elméletekkel ellentétben -, hogy az Egyesült Királyság elveti azt a lehetőséget, hogy az unió meghívja együttmüködésre. A probléma az lehet, hogy a Főképviselő meghívása aszimmetrikus kapcsolatot feltételez: az unió kialakít egy külpolitikai álláspontot, amelyhez (el)várja a csatlakozást a különböző országoktól. Ehhez képest az Egyesült Királyság más helyzetben van, és úgy tekint az EU-ra, mint egy lehetséges szereplöre a sok közül (USA, Kanada stb.), akivel elképzelhető az együttmüködés. Mindez pedig azzal a következménnyel járhat, hogy az Egyesült Királyság hasonlóan tekinthet magára, mint Svájc, amely hangsúlyozza autonóm és független külpolitikájának természetét. Ugyanakkor jelentős különbséget jelent e két utóbbi állam gyakorlata között, hogy az Egyesült Királyság kiemeli globális szerepét és felelősségvállalását, amelybe beletartozik a nemzetközi szankciós rezsimek kezdeményezése, pl. az ENSZ BT keretében.

\section{5. Összefoglaló}

A tanulmány az EU és az Egyesült Királyság közötti együttmüködést vizsgálta a nemzetközi szankciók kivetése területén. Miközben számos bizonytalanság terheli a jövőbeli kapcsolatokat, néhány fogódzkodó segít az eligazodásban. Ahogy arra a tanulmány is tett utalást, az átmeneti időszak alatt (elöreláthatóan 2020. december 31-ig) a britek átültetnek minden uniós szankciós rezsimet a kilépési megállapodás vonatkozó rendelkezései alapján. Másképp szólva, rövid távon nem várható eltérés a két fél szankciós politikái között. Ugyanakkor a kilépési megállapodás meghagy

${ }^{51}$ Lásd: Foreign Affairs Committee, Fragmented and Incoherent: the UK's sanctions policy': Government's Response to the Seventeenth Report (HC 2017-19, 2642-I), para 6. 
egy egérutat az Egyesült Királyság számára, amikor lehetővé teszi, hogy a britek figyelmen kívül hagyjanak bizonyos közös kül- és biztonságpolitikai határozatokat, amennyiben azok végrehajtása nemzeti érdekeikkel ellentétes. Meg kell ugyanakkor jegyezni, hogy a kilépési megállapodás ez utóbbit csak akkor teszi lehetővé, amennyiben az Egyesült Királyság a lojalitás alapelvével összhangban cselekszik és semmi olyan fellépést nem fogad el, amely ellentétes lenne az EU külkapcsolatai intézkedéseivel.

A kilépési megállapodás mellett fontos az uniós tagsággal nem rendelkező európai államok tapasztalata. Ez alapján kijelenthető, hogy alapvetően aszimmetrikus viszony áll fenn az EU és más európai államok között: a Főképviselő egyszerűen meghívja ezen országokat, hogy csatlakozzanak az EU szankciós rezsimjeihez. A meghívás elfogadása ugyanakkor, mint az az elemzésből is kiderült, rendkívül nagy eltéréseket mutat: míg a tagjelölt államok többsége és az EFTA-országok végrehajtják az uniós szankciós rezsimek 80-100 százalékát, más államok (pl. a tagjelöltek vagy a Keleti Partnerség partnerállamai) rendszeresen figyelmen kívül hagyják ezeket a meghívókat.

Az egyik fő tanulság az uniós tagsággal nem rendelkező európai országok tapasztalatából, hogy az Egyesült Királyság leginkább a svájci utat követheti a jövőben. A britek sajátos helyzetéből adódóan (pl. ENSZ BT állandó tagsága) nehezen elképzelhető jelenleg, hogy könnyen elfogadnának egy aszimmetrikus kapcsolatot az unióval a kül- és biztonságpolitika területén. Ugyanakkor az Egyesült Királyság és az unió együttműködése szükséges előfeltétel a nemzetközi szankciók hatékonyságának biztosítása érdekében. Így várhatóan az Egyesült Királyság és az EU is arra törekszik a jövőben, hogy szoros együttműködést hozzanak létre a szankciós politika területén.

\section{Hivatkozások}

Cardwell, Paul J. [2016]: Values in the European Union's Foreign Policy: An Analysis and Assessment of CFSP Declarations. European Foreign Affairs Review, 21. évf., 4. sz., 601-621. o.

De Vries, Anthonius W. - Portela, Clara-Guijarro-Usobiaga, Borja [2014]: Improving the Effectiveness of Sanctions: A Checklist for the EU. CEPS Special Report. Letölthető: https://www.ceps.eu/cepspublications/improving-effectiveness-sanctions-checklist-eu/.

Koutrakos, Panos [2000]: Is Article 297 EC a "reserve of sovereignty"? Common Market Law Review, 37. évf., 6. sz., 1339-1362. o.

Kuyper, Jan Pieter [1975]: Sanctions against Rhodesia: The EEC and the Implementation of General International Legal Rules. Common Market Law Review, 12. évf., 2. sz., 231-244. o. 
Szép, Viktor [2019]: Foreign Policy Without Unilateral Alternatives? EU Member State Interests and the Imposition of Economic Sanctions. In: Varju Márton (szerk.): Between Compliance and Particularism: Member State Interests and European Union Law. Springer, Cham.

Szép, Viktor - Van Elsuwege, Peter [2020]: EU Sanctions Policy and the Alignment of Third Countries: Relevant Experiences for the UK? In: Vara, Juan Santos - Wessel, Ramses A. - Pollak, Polly (szerk.): The Routledge Handbook on the International Dimension of Brexit. Routledge (megjelenés alatt).

Van der Loo, Guillaume [2016]: The EU-Ukraine Association Agreement and Deep and Comprehensive Free Trade Area: A New Legal Instrument for EU Integration without Membership. Brill Nijhoff, Leiden, Boston.

Whitman, Richard [2016]: The UK and EU Foreign, Security and Defence Policy after Brexit: Integrated, Associated or Detached? National Institute Economic Review, 238. évf., 1. sz., 43-50. o.

\title{
Abstract of the Article
}

\author{
After Brexit: Cooperation possibilities of the United Kingdom and the \\ European Union in the imposition of international sanctions \\ VIKTOR SZÉP - PETER VAN ELSUWEGE
}

Brexit has created many uncertainties concerning the cooperation possibilities of the UK and the EU in the imposition of international sanctions. Both of them are committed to establish a cooperation mechanism in the field of restrictive measures, however, its concrete form remains in the shadow. This study aims to use the experience of European countries (e.g. EFTA countries, candidate and potential candidate countries) that align their sanctions policies with the EU. It analyses the legal framework of third countries as well as British and EU official documents with the aim to establish different scenarios for the future. The main argument is that the UK is less likely to accept a hierarchical relationship with the EU in the field of foreign and security policy but will seek to establish a relationship based on cooperation and consultation.

JEL Codes: F15 Economic Integration, F10 General, F510 International Conflicts; Negotiations; Sanctions.

Keywords: Brexit; economic sanctions; common commercial policy; common foreign and security policy 